\title{
PERANAN AKUNTAN PUBLIK PADA PASAR MODAL SYARIAH
}

\author{
Oleh: Suhad, SE, M.SA \\ Dosen Syariah STAIN Kudus
}

\begin{abstract}
The development of the capital market shari'a implicated in the demands of stakeholders on the role of the public accountant in order to produce a report audited financial maximum more. Of course this is not an excessive, because it wants the real financial information and avoid the asymmetry of information. In the audit of course there are some differences with the conventional accounting report because in Islamic capital market report using the earlier shari'a. In this Sharia PSAK development is done with general PSAK but psak model is based on the shari'a with reference fatwa MUI. PSAK Shari'a is located in the PSAK 100-106 which consists of the conceptual framework presentation of sharia financial report, accounting murabahah, musyarakah, mudharabah, greeting, and istishna. Public Accountant on capital market shari'a course is required to pay attention to the aspects of that is on the value of Islam.
\end{abstract}

Keywords: Classification and type of the Audit the Audit Report

\section{A. Pendahuluan}

Pasar modal syariah merupakan instrumen keuangan yang mempunyai hubungan cukup erat dengan dengan sektor ekonomi dalam suatu negara. Pasar modal syariah di Indonesia mulai menunjukkan peranan penting dalam menggerakkan dana untuk pembangunan nasional diberbagai bidang. Peranan pasar modal syariah dalam hal ini adalah sebagai penghubung antara pemodal dengan perusahaan. Pasar modal syari'ah di Indonesia berkembang cukup pesat hal ini ditandai oleh berbagai indikator diantaranya adalah semakin maraknya para pelaku pasar modal syariah yang mengeluarkan efek-efek syariah selain saham-saham dalam Jakarta Islamic Index (JII).

Pinsip pasar modal syariah, yaitu bahwa akad yang terjadi antara pemilik harta dengan emiten harus jelas. Segala sesuatu tindakan maupun informasinya harus transparan dan tidak boleh asimeti informasi yang dapat menimbulkan 
keraguan yang dapat menimbulkan kerugian di salah satu pihak. Perkembangan perusahaan-perusahaan yang go public di Indonesia ini mengakibatkan peningkatan permintaan akan audit laporan keuangan. Setiap perusahaan yang go publik diwajibkan untuk menyampaikan laporan keuangan yang disusun sesuai dengan standar akuntansi keuangan syariah dan telah diaudit oleh akuntan publik yang terdaftar di Badan Pengawas Pasar Modal syariah.

Bagi perusahaan-perusahaan go public yang sahamnya sebagian dimiliki oleh masyarakat luas, maka informasi yang tepat, cepat dan terpercaya sangat dibutuhkan oleh investor untuk mengetahui posisi keuangan, hasil usaha dan perkembangan perusahaan yang pengelolaannya dipercayakan kepada manajemen. Untuk memperoleh informasi yang tepat, akurat dan dapat dipercaya laporan keuangan harus disajikan sesuai dengan prinsip-prinsip standar akuntansi syariah. Untuk memastikan kewajarannya maka laporan keuangan tersebut harus diaudit oleh akuntan yang independen. Fungsi utama akuntan adalah dalam rangka memberikan gambaran yang transparan mengenai posisi keuangan suatu perusahaan, baik yang akan menawarkan saham, menerbitkan obligasi dan efek lainnya.

Proses audit membutuhkan waktu sehinga kadangkadang berakibat pengumuman laba dan laporan keuangan menjadi tertunda. Jika terdapat penundaanyang tidaksemestinya dalam pelaporan keuangan, maka informasi yang dihasilkan akan kehilangan relevansinya. Namun untuk menyediakan informasi tepat waktu, seringkali diperlukan laporan mengenai seluruh aspek transaksi atau peristiwa lainnya, sehingga mengurangi keandalan informasi. Sebaliknya jika pelaporan ditunda sampai seluruh aspek diketahui, informasi yang dihasilkan mungkin sangat andal tetapi kurang bermanfaat bagi pengambilan keputusan. Sehingga dalam usaha mencapai keseimbangan antara relevansi dan keandalan, kebutuhan pengambil keputusan (decition making) merupakan pertimbangan yang menentukan bagi pihak-pihak yang berkompeten (stakeholders).

Standar Auditing yang ditetapkan oleh Ikatan Akuntan Indonesia (SA-IAI) khususnya standar pekerjaan lapangan diatur mengenai beberapa prosedur dalam penyelesaian 
pekerjaan lapangan seperti perlu adanya perencanaan atas akivitas yang akan dilakukan, pemahaman yang memadai atas struktur pengendalian intern dan pengumpulan buktibukti kompeten yang diperoleh melalui inspeksi, pengamatan, pengajuan pertanyaan dan konfirmasi sebagai dasar untuk menyatakan pendapat atas laporan keuangan. Karena adanya standar inilah maka ada kemungkinan akuntan publik akan menunda publikasi laporan audit atau laporan keuangan auditan apabila dirasakan perlu untuk memperpanjang masa audit. Hendriksen, (1992: 75) berpendapat bahwa ketepatan waktu berakibat laporan keuangan seharusnya disajikan pada suatu interval waktu, untuk menjelaskan perubahan dalam perusahaan yang mungkin mempengaruhi pemakai informasi dalam membuat prediksi dan keputusan. Ketepatan waktu penyusunan atau pelaporn suatu laporan keuangan perusahaan bisa berpengaruh pada niali laporan keuangan tersebut.

Nilai laporan Keuangan berubah secara berkebalikan dengan waktu untukmenyelesaikan penyusunannya (Kenley dan Stubus, 1972: 9). Apabila terjadi keterlambatan informasi akan berimplikasi reaksi negatif dari pelaku pasar modal syariah. Hal ini disebabkan laporan keuangan teraudit di dalamnya memuat informasi laba yang dihasilkan oleh perusahaan bersangkutan dijadikan sebagai salah satu dasar pengambilan keputusan (decition making) untuk membeli atau menjual kepemilikan yang dimiliki oleh investor. Artinya informasi laba dari laporan keungan yang dipublikasikan akan menyebabkan kenaikan atau penurunan harga saham. Keterlambatan pelaporan, secara tidak langsung juga diartikan oleh investor sebagai pertanda (signal) yang buruk bagi perusahaan.

Suatu proses sistematik untuk menghimpun dan mengevaluasi bukti-bukti secara obyektif mengenai asersiasersi tentang berbagai tindakan dan kejadian ekonomi untuk menentukan tingkat kesesuaian antara asersi-asersi tersebut dengan kriteria yang telah ditentukan dan menyampaikan hasilnya kepada pemakai yang berkepentingan (Halim, 1997: 1). Arens, Loebecke, (1996:1) mendefinisikan auditing sebagai: suatu proses pengumpulan dan pengevaluasian bahan bukti tentang informasi yang dapat diukur mengenai suatu entitas ekonomi yang dilakukan oleh seorang yang kompeten dan independn 
untuk dapat menentukan dan melaporkan kesesuaian informasi yang dimaksud dengan kriteria yang telah ditetapkan.

Dari definisi-definisi yang telah dikemukakan di atas, dapat disimpulkan bahwa setidaknya ada tiga elemen fundamental dalam auditing, yaitu pertama, seorang auditor harus independen. Kedua, auditor harus bekerja mengumpulkan bukti (evidence) untuk mendukung pendapatnya. Ketiga, hasil pekerjaan auditor adalah laporan (report). Laporan merupakan hasil yang harus disampikan auditor kepada pengguna laporan keuangan.

\section{B. Pembahasan}

\section{Klasifikasi Audit}

Menurut Kell dan Boyton (1996) dalam Halim (1997: 5) audit dapat diklasifikasikan berdasar tujuan dilaksanakannya audit. Dalam hal ini tipe audit terbagi ke dalam tiga kategori: Pertama, audit laporan keuangan (financial statement audit). Tujuannya untuk memberikan pendapat apakah laporan keuangan yang disajikan secara wajar sesuai dengan kriteria yang telah ditentukan yaitu Pernyataan Standar Akuntansi Keuangan (PSAK). Jadi ukuran kesesuaian audit laporan keuangan adalah kewajaran (fairness). Kedua, audit kepatuhan (compliance audit). Tujuannnya untuk menentukan apakah kegiatan finansial maupun operasi tertentu dari suatu entitas sesuai dengan kondisikondisi, aturan-aturan dan regulasi yang ditentukan. Kriteria yang ditentukan tersebut berasal dari berbagai sumber seperti manajemen, kreditor, maupun lembaga pemerintah. Ukuran kesesuaian audit kepatuhan adalah ketepatan (correctness). Ketiga, audit operasional (operational audit). Audit operasional meliputi penghimpunan dan pengevaluasian bukti mengenai kegiatan operasional organisasi dalam hubungannya dengan tujuan pencapaian efisiensi, efektivitas, maupun kehematan (ekonomis) operasional. Efisiensi adalah perbadingan antara masukan dengan keluaran, sedangkan efektifitas adalah pebandingan antara keluaran dan target yang ditetapkan.

Di Indonesia ada empat jenis auditor yang umum dikenal, yaitu : pertama, auditor independen (akuntan publik terdaftar). Auditor independen adalah para praktisi individual atau anggota kantor akuntan publik yang memberikan jasa auditing 
profesional kepada klien (Halim, 1997: 11). Klien dapat berupa perusahaan yang berorientasi laba, organisasi nirlaba, badanbadan pemerintahan maupun individu perorangan. Kantor akuntan publik sebagai auditor independen bertanggungjawab atas audit laporan keuangan historis dari seluruh perusahaan dan organisasi lainnya yang menjadi klien. Kedua, auditor pemerintah. Auditor pemerintah adalah auditor yang bekerja di instansi pemerintah yang tugas utamanya adalah melakukan audit atas pertanggungjawaban keuangan dari berbagai unit organisasi dalam pemerintahan (Halim, 1997: 11). Terdapat beberapa lembaga atau badan yang bertanggungjawab secara fungsional atas pengawasan terhadap kekayaan atau keuangan negara. Pada tingkatan tertinggi terdapat Badan Pemeriksa Keuangan (BPK), kemudian terdapat badan Pengawas Keuangan dan Pembangunan (BPKP) dan Inspektorat Jenderal pada departemen-departemen pemerintah.

Ketiga, auditor pajak. Direktorat Jenderal Pajak (DJP) yang berada di bawah Departemen Keuangan RI, bertanggung jawab atas penerimaan negara dari sektor perpajakan dan penegakan hukum dalam pelaksanaan ketentuan perpajakan. Aparat pelakasana DJP di lapangan adalah KPP (Kantor Pelayanan Pajak) dan Kantor Pemeriksa dan Penyidikan Pajak (Karikpa). Karipka mempunyai auditor-auditor khusus yang bertugas melakukan audit terhadap para wajib pajak tertentu untuk menilai kesesuaiannya dengan ketentuan perundangan perpajakan. Keempat,auditor intern. Auditor intern bekerja di suatu perusahaan untuk melakukan audit bagi kepentingan manajemen perusahaan. Bagian audit dari suatu perusahaan biasanya bertanggungjawab langsung kepada presiden direktur, direktur eksekutif atau kepada komite audit dari dewan komisaris. Pada BUMN, auditor intern berada di bawah SPI (Satuan Penagawasan Intern). Tujuan auditing internal adalah untuk membantu manajemen dalam melaksanakan tanggung jawabnya secara efektif (Halim, 1997: 11). Auditor internal terutama berhubungan dengan audit operasional dan audit kepatuhan. Meskipun demikian, pekerjaan auditor internal dapat mendukung audit atas laporan keuangan yang dilakukan auditor independen.

\section{Jasa yang Diberikan Kantor Akuntan Publik}


Jasa yang diberikan oleh para staf profesional suatu kantor akuntan publik dapat diklasifikasikan menjadi dua yaitu jasa atestasi dan jasa non atestasi.

1. Jasa Atestasi

Atestasi adalah suatu pernyataan pendapat atau pertimbangan sseorang yang independen dan kompeten mengenai kesesuaian, dalam segala hal yang signifikan, asersi suatu entitas dengan kriteria yang telah ditetapkan. Ada empat jenis jasa atestasi yang dapat diberikan oleh suatu kantor akuntan publik, yaitu: a)'Audit. Contoh utama jasa ini adalah audit atas laporan keuangan historis. Dalam audit laporan keuangan, klein menugaskan auditor untuk menghimpun dan mengevaluasi bukti yang berkaitan dengan laopran keuangan untuk memberikan pendapat mengenai kewajaran laporan keungan. Keyakinan yang diberikan adalah keyakinan positf (positive asurance). b) Pemeriksaan (Examination). Auditor dalam melaksanakan jasa ini akan memberikan pendapat atas asersi-asersi suatu pihak sesuai kriteria yang ditentukan. Keyakinan yang diberikan pada examination adalah keyakinan positif (positive assurance). Meskipun demikian tingkat keyakinan yang diberikan berada di bawah tingkat keyakinan laporan keuangan. c) Penelaahan (Review). Jasa review atau pengkajian ulang terutama dilakukan dengan wawancara dengan manajemen dan analisis komparatif informasi keuangan suatu perusahaan. Lingkup kerjanya lebih sempit daripada audit maupun examianation. Keyakinan yang diberikan pada review adalah keyakinan negatif (negative assurance). d) Prosedur yang Disepakati Bersama (Agreedupon Procedures). Lingkup jasa ini lebih sempit daripada audit maupun examination.

2. Jasa Non Atestasi

Jenis jasa non atestasi yang diberikan oleh suatu kantor akuntan publik trdiri dari : a) Jasa akuntansi. Jasa akuntansi dapat diberikan melalui aktivitas pencatatan, penjurnalan, posting, jurnal penyesuaian dan penyusunan laporan keuangan klien (jasa kompilasi) serta perancangan sistem akuntansi. b) Jasa perpajakan. 
Jasa perpajakan meliputi pengisian laporan pajak, dan perencanaan pajak. c) Jasa konsultasi manajemen. Jasa konsultasi manajemen atau management advisory services merupakan fungsi pemberian konsultasi dengan memberikan saran dan bantuan teknis kepada klien untuk peningkatan penggunaan kemampuan dan sumber daya untuk mencapai tujuan perusahaan klien

\section{Standar Auditing}

Akuntan publik memainkan peran sosial yang penting, sehingga manajemen KAP dan staf profesional mereka dituntut untuk berperilaku secara pantas dan melaksanakan audit dan jasa lainnya dengan kualitas tinggi. IAI dan organisasi terkait lainnya telah mengembangkan beberapa mekanisme untuk meningkatkan kualitas audit dan perilaku profesional. Mekanisme ini kemudian ditetapkan sebagai standar auditing yang ditetapkan Ikatan Akuntan Indonesia, dan menjadi kerangka (framework) interpretasi oleh IAI. Kesepuluh standar tersebut adalah:

a. Standar Umum

- Audit harus dilaksanakan oleh seseorang atau lebih yang memiliki keahlian dan pelatihan teknis cukup sebagai auditor.

- Dalam semua hal yang berhubungan dengan penugasan, independensi dalam sikap mental harus dipertahankan oleh auditor.

- Dalam pelaksanaan audit dan penyusunan laporannya, auditor wajib menggunakan kemahiran profesionalnya dengan cermat dan seksama.

b. Standar Pekerjaan Lapangan

- Pekerjaan harus direncanakan sebaik-baiknya dan jika digunakan asisten harus disupervisi dengan semestinya.

- Pemahaman yang memadai atas struktur pengendalian intern harus diperoleh untuk merencanakan audit dan menentukan sifat, saat dan lingkup pengujian yang harus dilakukan.

- Bukti audit kompeten yang cukup harus diperoleh melaui inspeksi pengamatan, pengajuan pertanyaan 
dan konfirmai sebagai dasar yang memadai untuk menyatakan pendapat atas laporan keuangan yang diaudit.

c. Standar Pelaporan

- Laporan auditor harus menyatakan apakah laporan keuangan telah disusun sesuai dengan prinsip akuntansi yang berlaku umum.

- Laporan audit harus menunjukkan keadaan yang di dalamnya prinsip akuntasi tidak secara konsisten diterapkan dalam penyusunan laporan keuangan periode berjalan dalam hubungannya dengan prinsip akuntasi yang diterapkan dalam periode sebelumnya.

- Pengungkapan informatif dalam laporan keuangan harus dipandang memadai, kecuali dinyatakan lain dalam laporan audit.

- Laporan audit harus memuat suatu pernyataan pendapat mengenai laporan keuangan secara keseluruhan atau suatu asersi bahwa pernyataan demikian tidak dapat diberikan. Jika pendapat secara keseluruhan tidak dapat diberikan, maka alasannya harus dinyatakan. Dalam semua hal yang mana auditor dihubungakan dengan laporan keuangan, laporan auditor harus memuat petunjuk yang jelas mengenai sifat pekerjaan auditor, jika ada dan tingkat tanggung jawab yang dipikulnya.

\section{Laporan Audit}

Laporan sangat penting dalam suatu audit atau proses atestasi lainnya karena laporan menginformasikan pmakai informasi mengenai apa yang dilakukan auditor dan kesimpulan yang diperolehnya.Dari sudut pandang pemakai, laporan dianggap sebagai produk atestasi. Bagianbagian dari laporan audit bentuk baku, yaitu pertama, Judul laporan. Standar auditing mengharuskan pemberian judul pada laporan dan judul itu harus memuat kata independen. Kedua, alamat yang dituju laporan audit. Laporan ini biasanya ditujukan kepada perusahaan yang bersangkutan, pemegang saham atau dewan direksi atau komisarisnya. 
Namun dalam beberapa tahun terakhir ini laporan sering ditujukan kepada para pemegang saham untukmenunjukkan auditor independen terhadap perusahaan, dewan direksi dan komisarisnya. Ketiga, paragraf pendahuluan. Paragraf ini merupakan pernyataan sederhana bahwa kantor akuntan publik bersangkutan telah melaksanakan suatu audit. Selanjutnya dicantumkan laporan keuangan yang diaudit termasuk tanggal neraca, dan periode-periode akuntansi untuk laporan laba rugi dan laporan arus kas.

Keempat, paragraf lingkup audit. Paragraf ini terlebih dahulu menyatakan bahwa auditor yang bersangkutan telah mengikuti standar auditing yang ditetapkan oleh Ikatan Akuntan Indonesia. Juga dibahas mengenai bahan bukti audit yang memadai sehingga dapat memberikan keyakinan bahwabahwa laporan keuangan bebas dari salah saji yang material. Kelima, paragraf pendapat. Paragraf terakhir dalam laporan audit standar memuat kesimpulan auditor berdasarkan hasil audit. Paragraf pendapat dengan tegas menyatakan bahwa yang diberikan adalah suatu pendapat dan bukan pernyataan mutlak atau jaminan. Keenam, tanda tangan dan nama akuntan public. Nama ini menunjukkan partner akuntan publik atau auditor yang bertanggungjawab atas audit yang dilakukan. Auditor membubuhkan tanda tangannya berikut noemer register negara yang bersangkutan. Ketujuh, tanggal laporan audit. Tanggal yang dipakai dalam laporan ini adalah tanggal saat auditor telah menyelesaikan bagian terpenting dari prosedur audit di lapangan. Pemberian tanggal atas laporan auditor independen menyebutkan bahwa tanggal selesainya pekerjaan lapangan harus digunakan oleh auditor sebagai tanggal laporan auditnya.

Tanggung jawab auditor terhadap peristiwa kemudian (subsequent event) dibatasi periodenya yaitu sejak tanggal neraca sampai dengan tanggal diselesaikannya pekerjaan lapang. Peristiwa kemudian yang yang terjadi setelah tanggal selesainya pekerjaan lapangan, meskipun mempunyai dampak terhadap unsur yang disajikan dalam laporan keuangan klien bukan lagi menjadi tanggung jawab auditor. Jika peristiwa kemudian yang memerlukan 
adjusment terhadap laporan keuangan terjadi setelah tanggal selesainya pekerjan lapangan, namun sebelum penerbitan laporan auditor dan auditor mengetahui tentang adanya peristiwa itu, laporan keuangan harus diadjust atau auditor harus memberikan pengecualian pada pendapatnya. Jika adjusment dilakukan tanpa pengungkapan peristiwa yang bersangkutan, laporan auditor harus diberi tanggal sesuai selesainya pekerjaan lapangan. Namun jika laporan keuangan diadjust dan pengungkapan tentang peristiwa tersebut dilakukan maka auditor dapat memilih 2 metode yaitu:

a) Tanggal ganda

Tanggal ganda ini memungkinkan auditor menyisipkan informasi penting dalam laporan keuangan klien. Tanggung jawab auditor yaitu setelah tanggal neraca sampai diselesaikannya pekerjaan lapang dan peristiwa yang spesifik.

b) Tanggal kemudian.

Digunakan tanggal tunggal dengan mengundur laporan auditnya, dari tanggal diselesaikannya pekerjaan lapangan ke tanggal terjadinya peristiwa yang menyebabkan auditor menggunakan tanggal kemudian. Tanggung jawab auditor yaitu sejak tanggal neraca sampai dengan tanggal terjadinya peristiwa yang menyebabkan auditor menggunakan tanggal kemudian (Mulyadi, 1998: 403).

\section{Jenis Pendapat Auditor}

Ada lima jenis pendapat yang dapat diberikan oleh auditor, yaitu:

a) Pendapat wajar tanpa pengecualian (unqualified opinion) Pendapat wajar tanpa pengecualian dapat diberikan auditor apabila audit telah dilaksanakan atau diselesaikan sesuai dengan standar auditing, penyajian laporan keuangan sesuai dengan prinsip akuntansi yang berlaku umum, dan tidak terdapat kondisi atau keadaan tertentu yang memerlukan bahasa penjelasan. Pendapat wajar tanpa pengecualian dengan tambahan bahasa penjelasan. Pendapat ini diberikan apabila audit telah dilaksanakan 
atau diselesaikan sesuai dengan standar auditing, penyajian laporan keuangan sesuai dengan prinsip akuntansi yang berlaku umum, tetapi terdapat keadaan atau kondisi tertentu yang memerlukan bahasa penjelasan. Kondisi atau keadaan yang memerlukan bahsa penjelasan tambahan antara lain dapat diuraikan sebagai berikut:

b) Pendapat auditor sebagian didasarkan atas laporan auditor independen lain.

Auditor harus menjelaskan hal ini dalam paragraf pengantar untuk menegaskan pemisahan tanggung jawab dalam pelaksanaan audit.

- Adanya penyimpangan dari prinsip akuntansi yang ditetapkan oleh IAI. Penyimpangan tersebut adalah penyimpangan yang dilakukan agar tidak menyesatkan laporan keuanganauditan. Auditor harus menjelaskan penyimpangan yang dilakukan berikut tafsiran pengaruh maupun alasan penyimpangan dilakukan dalam satu paragraf khusus.

- Laporan keuangan dipengaruhi oleh ketidakpastian yang material.

- Auditor meragukan kemampuan satuan usaha dalam mempertahanakan kelangsungan hidupnya.

- Auditor menemukan adanya suatu perubahan material dalam penggunaan prinsip dan metode akuntansi.

c) Pendapat wajar dengan pengecualian (qualified opinion)

Jenis pendapat ini diberikan apabila:

- Tidak ada bukti kompeten yang cukup atau adanya pembatasan lingkup audit yang material tetapi tidak mempengaruhi laporan keuangan secara keseluruhan.

- Auditor yakin bahwa laporan keuangan berisi penyimpangan dari prinsip akuntansi yang berlaku umum yang berdampak material tetapi tidak mempengaruhi laporan keuangan secara keseluruhan. Penyimpangan tersebut dapat berupa pengungkapan yang tidak memadai, maupun perubahan dalam prinsip akuntansi.

- Auditor harus menjelaskan alasan pengcualian dalam 
satu paragraf terpisah sebeklum paragraf pendapat.

d) Pendapat tidak wajar (adverse opinion)

Pendapat ini menyatakan bahwa laporan keuangan tidak menyajikan secara wajar posisi keuangan, hasil usaha dan arus kas esuai dengan prinsip akuntansi yang berlaku umum. Audito harus menjelaskan alasan pendukung pendpat diadk wajar dan dampak utama dari hal yang menyebabkan pendapat diberikan terhadap laporan keuangan. Misalnya penyimpangan dari prinsip akuntansi yang berlaku umum seperti perusahaan menggunakan penilaian aktva berdasarkan nilai appraisal dan mendepresiasi atas dasar nilai tersebut. Penjelasana tersebut harus dinyatakan dalam paragraf terpisah sebelum paragraf pendapat.

e) Pernyataan tidak memberikan pendapat (disclaimer opinion)

Pernyataan uditor tidak mmberikan pendapat ini layak diberikan apabila:

- Adanya pembatasan ruamg lingkup audit yang sangat material baik oleh klien maupun karena kondisi tertentu.

- Auditor tidak independen terhadap klien.

Pernyataan ini tidak dapat diberikan apabila auditor yakin bahwa teerdapat penyimpangan yang material dari prinsip akuntansi yang berlaku umum. Auditor tidak diperkenankan mencantumkan paragraf ruang lingkup audit apabial ia menyatakan unntuk tidak memberikan pendapat. Ia harus menyatakan alasan mengapa auditnya tidak berdaarkan standar auditing yang ditetapkan IAI.

Peranan akuntan sebagai salah satu profesi penunjang pasar modal syariah adalah penting. Sedangkan tanggung jawab akuntan di pasar modal syariah antara lain: Pertama, tanggung jawab yuridis dalam hubungannya dengan pernyataan pendapat akuntansi yang disampaikan kepada masyarakat. Opini akuntan dan penyampaian informasi lainnya harus sesuai dengan standar profesi dan peraturan pasar modal syariah yang berlaku. Pelaksanaan penugasan akuntan di pasar modal syariah tidak terlepas dari kemungkinan adanya tuntutan atau gugatan baik administratif, perdata maupun pidana. 
Kedua, tanggung jawab finansial dalam hubungan dengan kemungkinan munculnya kerugian yang diderita pihak ketiga. Hal ini dapat pula mengakibatkan tuntutan ganti rugi dari pihak-pihak yang merasa dirugikan. Ketiga, tanggung jawab moral dalam hubungan dengan kewajaran akuntansi, untuk menjunjung kode etik akuntan serta selalu menjaga sikap mental yang independen. Hal ini perlu mengingat profesi akuntan sebagai profesi yang dipercaya oleh masyarakat luas harus selalu menjaga kepercayaan yang diberikan dan menghindari tindakan yang dapat merugikan masyarakat.

Setiap perusahan yang akan go public maupun yang sudah go public disyaratkan untuk membuat laporan keuangan. Perusahaan go public berkewajiban menyampaikan laporan keuangan berkala. Laporan keuangan berkala yang dimaksud adalah laporan keuangan tahunan dan laporan keuangan tengah tahunan. Setiap emiten dan perusahaan publik yang pernyataan pendaftarannya telah efektif wajib menyampaikan laporan keuangan berkala kepada Bapepam. Laporan keuangan yang harus disampaikan ke Bapepam terdiri dari neraca, laporan laba rugi, laporan saldo laba, laporan arus kas, catatan atas laporan keuangan dan laporan lain serta materi penjelasan yang merupakan bagian integral dari laporan keuangan jika dipersyaratkan seperti laporan komitmen dan kontijensi untuk emiten dan perusahaan publik yang bergerak dalam bidang perbankan.

Ketepatan waktu penerbitan laporan keuangan auditan merupakan hal yang sangat penting khususnya untuk perusahaan-perusahaan publik yang menggunakan pasar modal sebagai salah satu sumber pendanaan. Beaver (1968) seperti yang dikutip dalam Hanipah (2001) berpendapat bahwa berkaitan dengan isi informasi keuangan yang berupa pengumuman laba dimana investor akan menunda pembelian atau penjualan sekuritasnya sampai dengan laporan keuangan auditan diterbitkan. Manajemen perusahaan sangat menghargai jika auditor mampu menyelesaikan pekerjaannya tepat waktu. Namun auditor memerlukan waktu yang cukup untuk dapat mengumpulkan bukti-bukti kompeten yang dapat mendukung opininya 


\section{Simpulan}

Pasar modal syariah merupakan solusi alternatif bagi masyarakat yang ingin menginvestasikan hartanya. Oleh sebab itu tidak cukup berinvestasi akan tetapi tentu memperhatikan bagaimana kondisi perusahaan tersebut. Dengan melihat informasi keuangan suatu perusahaan tentu kita bisa mengambil keputusan (decition making). Ekspekasi investor dan pemilik perusahaan serta pihak-pihak yang berkepentingan terhadap informasi keuangan (stakeholders), yaitu informasi yang mencerminkan sesungguhnya bukan sebaliknya malah terjadi asimetri informasi atau kesenjangan informasi. Laporan keuangan auditan yang dipublis selama ini di pasar modal syariah memiliki manfaat yang sangat esensial. Disinilah akuntan publik dituntut bekerja berdasarkan standar yang ada dan memperhatikan kode etik serta independensi seorang auditor. 
Suhadi, SE, M.SA

\section{DAFTAR PUSTAKA}

Arens, Alvin A., and James K. Loebbecke, 1996, Auditing: Pendekatan Terpadu, Adaptasi oleh Amir Abadi Yusuf, Salemba Empat, Jakarta.

Boyton, W.C, and Walter G. Kell, 1996, Modern Auditing, Sixth Edition, John Wiley \& Sons Inc, New York.

Halim, Abdul, 1997, Auditing: Dasar-dasar Audit Laporan Keuangan, UUAMP YKPN, Yogyakarta.

Halim, Varianada, 2000, Faktor-faktor yang Mempengaruhi Audit Delay, Jurnal Bisnis dan Akuntansi, Vol. 2 No. 1, p. 63-75.

Hanipah, 2001, Analisis Faktor-faktor yang Mempengaruhi Lamanya Penyelesaian Audit (Studi Empiris pada PerusahaanPerusahaan Manufaktur di BEJ), Skripsi, Universitas Brawijaya, Malang.

Hendriksen, E.S., 1992. Accounting Theory, 5th Edition, Homewood Illinois:Irwin. Inc

Kenley, W.J. and G.J. Stubus. Stubus. Objective And Concepts Of Financial Statements. Accounting Research Study. 3.

Mulyadi, Kanaka Puradiredja, 1998, Auditing, Edisi kelima, Salemba Empat, Jakarta. 